\title{
AKSIOLOGI REOG PONOROGO RELEVANSINYA DENGAN PEMBANGUNAN KARAKTER BANGSA
}

\author{
Asmoro Achmadi \\ Institut Agama Islam Negeri (IAIN) Walisongo Semarang \\ e-mail:asmoro_achmadi@yahoo.com
}

\begin{abstract}
The study has been chosen because it is very interesting to explore. Indonesia has diverse arts and cultures in its tradition. Within such diversities, there are significant values to develop the national character, one of them being that of Reog Ponorogo. The purpose of this research is to reveal that the art of Reog is attractive and full of magnificent values. During this reform era, in which corruptible practices and radicalism are rampant, the values contained in the Reog art can be used as a foundation for better national character building. The methods used in this study were hermeneutics and heuristics. The former was employed to disclose the meaning contained in the research object in the form of life phenomenon through understanding and interpretation, while the latter was used to discover and develop other new methods in science especially philosophy. The result of this research is that the art of Reog Ponorogo is part the typically original culture from Ponorogo. When viewed from the perspective of hierarchical values, Reog contains holiness, spiritual, living, and joyful values. The Indonesian nation currently faces corruption, terrorism, radicalism, and globalization challenges that may lead to the weakling of the national character. The values of Reog art can be used as a source of inspiration and may contribute to the character building of the nation. What needs to be presented is the strengthening of the four pillars of the nation and the reflection of the five essential virtues of the Reog art.
\end{abstract}

Abstrak:Tema ini dipilih karena sangat menarik untuk dijelajahi. Indonesia memiliki beragam seni dan budaya dalam tradisi.Dalam keberagaman tersebut, ada nilai-nilai yang signifikan untuk mengembangkan karakter nasional, salah satunya adalah bahwa Reog Ponorogo.Tujuan dari penelitian ini adalah untuk mengungkapkan bahwa seni Reog menarik 
ASMORO ACHMADI: Aksiologi Reog Ponorogo...

dan penuh dengan nilai-nilai yang luar biasa.Selama era reformasi ini, di mana praktek-praktek yang fana dan radikalisme yang merajalela, nilai-nilai yang terkandung dalam seni Reog dapat digunakan sebagai landasan untuk membangun karakter bangsa yang lebih baik.Metode yang digunakan dalam penelitian ini adalah hermeneutika dan heuristik.Yang pertama digunakan untuk mengungkapkan makna yang terkandung dalam objek penelitian dalam bentuk fenomena kehidupan melalui pemahaman dan interpretasi, sedangkan yang kedua digunakan untuk menemukan dan mengembangkan metode baru lainnya dalam ilmu terutama filsafat.Hasil dari penelitian ini adalah bahwa seni Reog Ponorogo adalah bagian budaya biasanya asli dari Ponorogo. Bila dilihat dari perspektif nilai-nilai hirarkis, Reog mengandung kekudusan, spiritual, hidup, dan nilai-nilai yang menyenangkan.Bangsa Indonesia saat ini menghadapi korupsi, terorisme, radikalisme, dan tantangan globalisasi yang dapat menyebabkan lemahya karakter nasional.Nilai-nilai seni Reog dapat digunakan sebagai sumber inspirasi dan dapat berkontribusi pada pembentukan karakter bangsa.Apa yang perlu disajikan adalah penguatan empat pilar bangsa dan refleksi dari lima kebajikan penting dari seni Reog.

Keywords: reog Ponorogo, nilai, karakter bangsa, Babad Ponorogo, seni rupa, seni pertunjukan.

\section{A. Pendahuluan}

Setiap diri manusia memiliki aspek-aspek kehidupan yang meliputi filsafat, kepercayaan, ilmu, dan seni. ${ }^{1}$ Keempat aspek tersebut saling berinteraksi dan saling melengkapi menjadi satu sistem yang utuh. Hal ini menunjukkan bahwa semua manusia selalu menyisihkan sebagian waktunya untuk memenuhi kepuasan batinnya melalui berbagai ungkapan baik kepercayaan, filsafat, ilmu maupun seni. Seni secara garis besar terbagi menjadi dua kelompok, yaitu seni rupa dan seni pertunjukan. Seni dari aspek ragamnya terbagi menjadi tiga cabang seni, yaitu seni musik, seni tari, dan seni teater. Seni juga memiliki tiga fungsi utama, yaitu seni sebagai sarana 
ASMORO ACHMADI: Aksiologi Reog Ponorogo...

ritual, seni sebagai sarana hiburan, dan seni sebagai sarana penyajian estetis.

Salah satu kesenian yang terkenal dan melegenda yaitu kesenian reog Ponorogo merupakan sebuah seni budaya oleh UNESCO (United Nation Educational Scientific and Cultural Organization) ditetapkan sebagai salah satu seni pertunjukan asli. ${ }^{2}$ Kesenian tersebut secara umum termasuk salah satu kekayaan kebudayaan Jawa yang sarat dengan nilai-nilai adiluhung (keutamaan). Masyarakat Ponorogo dengan kesenian reognya sangat bangga terhadap kesenian yang dimilikinya.Kesenian reog juga menjadi sumber inspirasi dan oleh karenanya masyarakat Ponorogo dapat memberikan apresiasi setinggi mungkin terhadap kesenian tersebut. Perkembangan kesenian reog hingga saat ini telah memperlihatkan perkembangan yang menggembirakan, karena kesenian reog telah berkembang tidak hanya ke seluruh Nusantara tetapi juga keseluruh dunia. Koentjaraningrat mengemukakan bahwa kesenian reog Ponorogo sebagai tarian raksasa yang dinamakan reog dari Ponorogo. Kesenian reog Ponorogo sebagai kesenian berkelompok meliputi: pemimpin rombongan (warok), penari tokoh raksasa (barongan), penari topeng (tembem), penari kuda (jathil), penari klana, dan penabuh alat-alat gamelan (gong, kethuk, trompet kayu, kendhang, dan kempul). ${ }^{3}$

Sejalan dengan kondisi bangsa Indonesia sebagai dampak negatif reformasi ditambah merebaknya korupsi, kejahatan, kekerasan, derasnya budaya asing yang cenderung merusak, dan lunturnya rasa nasionalisme. Berbagai aksi kekerasan yang sering muncul dengan mengatasnamakan agama telah memasuki ranah ideologi. Agama telah menjadi bagian kebenaran yang harus dipertahankan dan diperjuangkan dengan berbagai cara. Tindakan kekerasan dengan cara-cara yang hakikatnya 'melawan' teks agama dengan tafsiran yang keras, radikal, maupun fundamental. ${ }^{4} \mathrm{Hal}$ tersebut dapat merusak sendi-sendi kepribadian bangsa, sehingga 
ASMORO ACHMADI: Aksiologi Reog Ponorogo...

menimbulkan kondisi karakter masyarakat dan bangsa melemah dan memprihatinkan.Upaya yang harus dilakukan adalah memperkuat ketahanan kebudayaan nasional maupun daerah melalui penggalian dan pengembangan nilai-nilai budaya, salah satunya adalah kesenian reog Ponorogo.Kesenian reog Ponorogo adalah sebuah seni-budaya kedaerahan yang memiliki kekhasan dan melegenda.

Di Ponorogo terdapat sebuah kesenian tradisional yang masih satu rumpun dengan kebudayaan Jawa sarat dengan nilai-nilai keutamaan.Kesenian reog dilahirkan, melegenda, dan menjadi besar karena masyarakat Ponorogo sangat memelihara dari generasi tua diturunkan ke generasi muda.Kesenian reog sampai saat ini telah berkembang ke seluruh kota-kota besar di Indonesia, sehingga setiap tahunnya diadakan festival (tahunan) nasional kesenian reog.Terkait dengan melemahnya kondisi karakter bangsa sekarang ini karena diakibatkan maraknya korupsi dan berbagai tindak kekerasan, maka nilai-nilai kesenian reog diharapkan dapat direfleksikan untuk membangun karakter bangsa.Pemikiran-pemikiran tentang nilainilai kesenian reog muncul saat Bathara Katong membangun masyarakat Ponorogo, dan menjadikan kesenian reog sebagai media mempersatukan masyarakat Ponorogo.

Permasalahannya sekarang, apa nilai-nilai aksiologis yang terungkap dalam kesenian reog Ponorogo, dan relevansinya antara nilai-nilai aksiologis dengan pembangunan karakter bangsa.

\section{B. Tentang Nilai}

Teori nilai atau aksiologi di dalamnya memuat berbagai hal, yaitu sifat dasar nilai, ragam nilai, ukuran nilai, dan kedudukan metafisis nilai. Sifat dasar nilai dikemukakan Max Scheler:"that they are qualities which are independent of goods; goods are valuable things. This independence includes every qualities do not vary with things. They are empirical form, i.e., values are a priori qualities. Values 
ASMORO ACHMADI: Aksiologi Reog Ponorogo...

as independent qualities do not vary with things. They are absolute; they are not conditioned by any act, regardless of its nature, be it historical, social, biological or purely individual".5 Ragam nilai dikemukakan Walter Everett digolongkan menjadi delapan kelompok, yaitu: nilai ekonomis, nilai kejasmanian, nilai hiburan, nilai sosial, nilai watak, nilai estetis, nilai intelektual, dan nilai keagamaan. ${ }^{6}$ Ukuran nilai, menurut Kattsoff ${ }^{7}$ bahwa nilai dapat diklasifikasikan dalam beberapa hal, yaitu: nilai instrinsik dan nilai instrumental. Nilai instrinsik adalah nilai yang dari sesuatu sejak semula sudah bernilai.Nilai instrumental adalah nilai dari sesuatu karena dapat dicapai sebagai sarana untuk mencapai tujuan sesuatu.Kedudukan metafisis dari nilai, apakah hubungan nilai-nilai dengan fakta-fakta yang diselidiki oleh ilmu alam, dari pengalaman manusia dari pengalaman manusiawi tentang nilai dengan kenyataan yang bebas dari manusia. Titus, Smith, dan Nolan ${ }^{8}$ mengemukakan bahwa nilai juga memiliki aliran-aliran, yaitu: subjektivisme dan objektivisme. Aliran subjektivisme mengatakan bahwa nilai menunjukkan perasaan atau emosi dari suka atau tidak suka.Makan, minum, mendengarkan musik semua itu bernilai karena membangkitkan rasa senang dan menimbulkan pengalamanpengalaman yang disukai.Aliran objektivisme mengatakan bahwa nilai itu objektif.Artinya, nilai-nilai itu terdapat di dunia ini harus digali.

Teori yang dipakai dalam menganalisis dan mencari nilai-nilai dalam kesenian reog Ponorogo adalah teori nilai dari Max Scheler. Max Scheler mengemukakan bahwa:

nilai memiliki hierarki terdiri empat tingkatan. Tingkatan pertama sebagai tingkatan tertinggi adalah nilai-nilai kesucian atau keprofanan.Tingkatan kedua adalah nilai-nilai spiritual.Tingkatan ketiga adalah nilai-nilai kehidupan.Tingkatan keempat sebagai tingkatan terendah adalah nilai-nilai kesenangan.Hierarki nilai ini di dalamnya terdapat hierarki dari tingkat yang lebih tinggi menurun hingga ke tingkat yang lebih rendah yang bersifat 
ASMORO ACHMADI: Aksiologi Reog Ponorogo...

apriori.Hierarki ini tidak dapat dideduksikan secara empirik, melainkan melalui tindakan preferensi (melalui intuisi-evidensi), dan hierarki ini sifatnya mutlak dan mengatasi segala perubahan historis serta membangun suatu sistem acuan absolut dalam etika, yang merupakan dasar untuk mengukur atau menilai berbagai kepercayaan dan perubahan moral dalam sejarah. ${ }^{9}$

Masalah nilai erat kaitannya dengan fakta kehidupan seharihari. Manusia hidup tidak dapat terlepas dari peranan nilai.Arti nilai sendiri adalah sesuatu yang ingin dicapai oleh seseorang, atau sesuatu yang dicita-citakan dalam hidupnya.Max Sheler menyatakan bahwa nilai mempunyai peranan sebagai daya tarik, dasar bagi tindakan, mendorong manusia untuk mewujudkan nilai-nilai yang ditemukan, dan pengarah bagi pembentukan diri manusia melalui berbagai tindakan sesuai tipe-tipe person bernilai. Peran nilai sebagai daya tarik dan pendorong akan memacu dan memberikan motivasi hidup manusia ke arah hidup lebih baik. Konsep tipe-tipe person bernilai seperti dikemukakan Max Scheler adalah masuk dalam waktu dan sejarah dengan perwujudan parsial dalam model person historis. Konsep tipe-tipe person bernilai apabila diperluas pemahamannya, maka akan muncul beberapa konsep person manusia bernilai, seperti: manusia unggul, manusia utama atau manusia super.

Untuk mengkaji reog Ponorogo ini, penulis merujuk buku Babad Ponorogo (jilid I-VIII) karangan Purwowijoyo dan juga diambil dari observasi partisipasi, wawancara, dan pengamatan lapangan dimana kesenian reog lahir dan dibesarkan. Sedangkan analisis data yang digunakan dalam penelitian ini adalah hermeneutika dan heuristika.Hermeneutika dipakai dalam upaya menangkap muatan nilai-nilai, sedangkan tujuan hermeneutika untuk mencari dan menemukan makna yang terkandung dalam objek penelitian berupa fenomena kehidupan. ${ }^{10}$ Hermeneutika ini dipakai untuk menangkap nilai-nilai dalam kesenian reog baik yang terlihat, tersamar maupun tersembunyi.Metode heuristika dipakai untuk menemukan dan 
ASMORO ACHMADI: Aksiologi Reog Ponorogo...

mengembangkan metode baru dalam suatu ilmu pengetahuan bahkan pada filsafat itu sendiri.11Tujuannya disamping mencari aspek-aspek aksiologis dalam kesenian reog, juga merefleksikan dan mentransformasikan nilai-nilai tersebut dalam pembangunan karakter bangsa.Hal sejalan dengan melemahnya karakter bangsa yang saat ini sedang dilanda berbagai krisis multi dimensi.

\section{Sejarah Kesenian Reog Ponorogo}

Wilayah Ponorogo adalah daerah kabupaten yang berada di baratdaya Provinsi Jawa Timur, berbatasan dengan Provinsi Jawa Tengah, diapit gunung Lawu dan gunung Wilis. Ponorogo didirikan tahun 1486 oleh Raden Katong (Bupati I) yang masih keturunan Raja Brawijaya V. Ponorogo sebelum diperintah Raden Katong merupakan kademangan Wengker dengan raja Klana Sewandana dan patih Klana Wijaya dikenal sangat sakti. Setelah kerajaan Wengker dikalahkan Airlangga sejarah kerajaan Wengker selesai.Selang dua ratus tahun berdirilah kademangan Bantarangin didirikan keturunan Klana Wijaya yaitu Ki Ageng Kutu Suryangalam yang dikenal sakti tiada tanding. ${ }^{12}$

Cerita kesenian reog Ponorogo memiliki beberapa versi.Pertama, Klana Sewandana raja kerajaan Bantarangin melamar putri raja Kediri Dewi Sanggalangit.Salah satu syarat lamaran adalah dibuatkan gamelan model baru dan manusia berkepala harimau.Gamelan tersebut sebagai cikal bakal kesenian reog saat itu disebut gumbung.Kedua, Ki Ageng Kutu sebagai abdi raja Brawijaya V memilih meninggalkan Majapahit, karena Brawijaya V tidak dapat menguasai kerajaan dan lebih dikuasai isterinya.Ki Ageng Kutu di daerah Wengker mendirikan padepokan Surukubeng melatih para muda berlatih ilmu kanuragan dengan permainan barongan. Barongan tersebut sebagai sindiran terhadap Raja Brawijaya V, sehingga Ki Ageng Kutu dianggap mbalelo atau memberontak. Brawijaya V sangat sulit menaklukkan Surukubeng, maka diutuslah Raden Katong menaklukkannya dan berhasil.Akhirnya, Raden 
ASMORO ACHMADI: Aksiologi Reog Ponorogo...

Katong diserahi tanah perdikan Wengker. ${ }^{13}$ Ketiga, sebelum Raden Katong menguasai Wengker, Ki Ageng Kutu menciptakan barongan yang menjadi permainan para warok.Setelah Ki Ageng Kutu dikalahkan Raden Katong, maka Raden Katong memandang perlu melestarikan barongan sebagai media dakwah Islam. ${ }^{14}$ Barongan yang dahulu dipunyai para warok sekarang menjadi milik masyarakat Ponorogo dan diganti nama reog. Kata reog berasal dari kata riyokun artinya khusnul khatimah.Maksudnya, perjuangan Raden Katong dan kawan-kawannya diharapkan menjadi perjuangan yang diridhai Tuhan.

Cerita kesenian reog Ponorogo memiliki keterkaitan dengan: 1) Perjuangan Raden Katong sebagai penyebar Islam pertama kali, sehingga sampai sekarang Ponorogo dikenal dengan berbagai pondok pesantren baik tradisional maupun modern, terutama ponpes modern Gontor, 2) Berdirinya kota Ponorogo dimana Raden Katong sebagai adipati pertama, karena Raden Katong pendiri kota Ponorogo, 3) Upaya pelestarian dan pengembangan kesenian reog yang melegenda dan menjadi kebanggaan masyarakat Ponorogo, baik di daerahnya sendiri maupun orang-orang Ponorogo di perantauan.

Perkembangan kesenian reog dimulai dengan kerajaan Wengker. Hal ini disebutkan Purwowijoyo ${ }^{15}$ mengemukakan kirakira empat setengah abad yang lalu sebelum nama Ponorogo terdapat Kademangan Surukubeng, desa Kutu, kecamatan Jetis yang dahulu menjadi kekuasaan Majapahit. Penguasanya bernama Ki Demang Gedhe Ketut Suryangalam, agamanya Budha memiliki badan tinggi besar banyak rambut di dada, kulit hitam, mata lebar terlihat sadis, pemberani, kaya ilmu kadigdayaan, besar pengaruhnya, dan menjadi guru sakti. Perkembangan kedua adalah di zaman Raden Katong setelah menjadi Bupati I bergelar Bathara Katong memakai kesenian reog untuk dijadikan media mengumpulkan massa (dakwah). Kesenian reog di masa Bathara 
ASMORO ACHMADI: Aksiologi Reog Ponorogo...

Katong, peran gemblakan diganti dengan penari jathil yang menggambarkan seorang prajurit sedang berlatih perang. ${ }^{16}$

Perkembangan kesenian reog di masa penjajahan oleh Belanda dan Jepang tidak diperbolehkan beraktivitas melebihi batas yang telah ditentukan, seperti mengumpulkan massa. ${ }^{17}$ Perkembangan kesenian reog di zaman orde lama yaitu sekitar tahun 1960-an, kesenian reog perkembangannya sangat pesat, karena kesenian tersebut dipakai partai politik untuk sarana mengumpulkan massa. Menjelang tahun 1965, muncul beberapa organisasi kesenian, seperti: BREN (Barisan Reog Nasional) didirikan oleh Partai Nasional Indonesia. CAKRA (Cabang Reog Agama) didirikan oleh Nahdhatul Ulama.Kesenian reog di masa Orde Baru (setelah peristiwa G-30PKI) perkumpulan reog tinggal BREN dan CAKRA. Tahun 1970-an di sekolah-sekolah dibentuklah kesenian reog mini dengan tujuan pelestarian kesenian reog melalui pendidikan.Tahun 1977 muncul INTI (Insan Takwa Illahi) yaitu perkumpulan kesenian reog (bentukan GOLKAR) tugasnya mengamankan pemilu. Tahun 1995 kesenian reog mendapatkan sertifikat hak cipta dan paten dari Departemen Kehakiman RI Nomor 013195 tanggal 12 April 1995.Tahun 1997 untuk pertama kali diadakan FRN (Festival Reog Nasional) tujuannya untuk meningkatkan kesejahteraan masyarakat dan mengembangkan kesenian reog agar lebih menasional.Tahun 2000 dibuatlah panggung permanen kesenian reog di aloon-aloon Ponorogo untuk tempat pentas seni-budaya.Pelaksanaan FRN dilaksanakan bersama dengan Grebeg Suro atau Tahun Baru Islam.Di masa reformasi kesenian reog dimunculkan dengan gairah dan semangat baru, yaitu disamping acara tahunan juga setiap bulannya diadakan pentas bulan purnama.Hingga sekarang, kesenian reog Ponorogo terdiri dua jenis yaitu reog pentas dan reog obyogan.Reog pentas adalah kesenian reog yang dipentaskan di FRN dan pentas bulan purnama (pentasnya di aloon-aloon).Reog obyogan adalah kesenian reog yang hidup dipedesaan (pentasnya di pelataran atau di jalan). 
ASMORO ACHMADI: Aksiologi Reog Ponorogo...

\section{Nilai-nilai Aksiologi Kesenian Reog Ponorogo}

Berbicara tentang nilai, dalam dunia filsafat banyak pemikiran tentang nilai. Seperti, Max Sheler, Walter G. Everett, dan sebagainya. Teori nilai yang dipakai dalam penelitian adalah teori nilai dari Max Scheler yang terbagi menjadi empat tingkatan, yaitu: pertama, nilainilai keruhanian meliputi: nilai dakwah, nilai kelestarian, nilai kepercayaan, dan nilai magis. Kedua, nilai-nilai spiritual meliputi: nilai budaya, nilai keindahan, nilai moral, nilai seni, nilai simbolik, dan nilai superioritas. Ketiga, nilai-nilai kehidupan meliputi: nilai kepahlawanan, nilai keadilan, dan nilai kesejahteraan. Keempat, nilai-nilai kesenangan meliputi: nilai hiburan, nilai kepuasan, nilai kompetitif, nilai material, dan nilai pertunjukan.

Teori nilai Max Scheler ini apabila dipakai untuk membedah kesenian reog Ponorogo, maka akan ditemukan beberapa nilai. Pembedahan tersebut dengan metode hermenetika dan heuristika. Nilai-nilai yang terungkap dalam kesenian reog adalah:

\section{Nilai-nilai Keruhanian}

Nilai-nilai Keruhanian meliputi: a) Nilai dakwah. Nilai ini terungkap pada gamelan reog yang dipakai sebagai media dakwah saat Bathara Katong menyebarkan Islam ke masyarakat Ponorogo yang masih menganut Hindhu.Gamelan reog yang dahulu disebut gumbung dipakai kerajaan Wengker untuk mengiringi dalam latihan perang.Metode Bathara Katong ini seperti metode dakwah yang dipakai para walisongo dalam mengislamkan tanah Jawa dengan media wayang purwa. Saksono mengatakan bahwa terdapat faktor eksteren atau 'awamilil kharijiyah yaitu dari karakter ajaran Islam yang disiarkan Walisongo (=Bathara Katong) banyak unsur Islam yang memiliki kesamaan dan kesesuaian dengan unsur-unsur Indonesia asli. ${ }^{18}$ Perayaan-perayaan hari besar Islam sekarang juga banyak menggunakan kesenian reog untuk membuat keramaian dan efektif mengumpulkan masyarakat.Nilai dakwah juga terlihat pada 
ASMORO ACHMADI: Aksiologi Reog Ponorogo...

kalung merjan (tasbih) ditambahkan pada paruh burung merak yang melambangkan ajaran Islam. ${ }^{19}$ b) Nilai kelestarian. Nilai ini terungkap sejak upaya Bathara Katong menaklukkan Ki Ageng Kutu dengan pendekatan kultural.Upaya kelestarian itu hingga sekarang masih dilakukan Pemerintah Daerah Tingkat II Ponorogo sebagai upaya kesinambungan. Upaya tersebut antara lain: buku Babad Ponorogo (jilid 1-VIII) karangan Purwowijoyo dijadikan buku babon sejarah Ponorogo. Menyusun buku Hari Jadi Kota Ponorogo (Bathara Katong Bapak-e Wong Ponorogo).Menyusun buku Pedoman Dasar Kesenian Reog Ponorogo dalam Pentas Budaya Bangsa.Menyusun buku Ponorogo dari Waktu ke Waktu. Mengadakan ritual budaya, seperti: ziarah ke makam Bathara Katong, Grebeg Suro, festival reog nasional, dan pentas bulan purnama. Kesenian reog Ponorogo dipatenkan: N0. 03195, tanggal 12 April 1995. c) Nilai kepercayaan. Nilai kepercayaan merupakan anggapan atau keyakinan bahwa sesuatu yang dipercayai itu benar-benar atau nyata; sebutan bagi sistem religi diIndonesia yang tidak termasuk salah satu dari kelima agama resmi.Kepercayaan atau religi menurut Endraswara bahwa religi memiliki dua artian. Pertama, religi adalah agama yang didasarkan wahyu, karena religi tidak dapat dijangkau oleh daya pikir apalagi dicari kebenarannya. Kedua, religi dalam artian luas yaitu meliputi variasi pemujaan, spiritual, dan sejumlah praktek hidup yang telah bercampur dengan budaya. Misal, magis, nujum, pemujaan pada benda atau binatang, tahayul, dan sebagainya. Nilai ini terungkap pada perlengkapan sesaji yang telah menjadi tradisi apabila pertunjukan reog akan mulai. Tujuan sesaji adalah agar terhindar dari gangguan orang maupun lelembut atau makhluk halus. Sesaji dilakukan di muka barongan dan tempat dhanyang desa. ${ }^{20}$ d) Nilai magis. Istilah magis menurut Frazer mengemukakan segala sistem tingkah laku dan sikap manusia untuk mencapai suatu maksud dengan menguasai dan mempergunakan kekuatankekuatan dan kaidah-kaidah gaib yang ada dalam alam. Artinya, sesuatu cara tertentu yang diyakini dapat menimbulkan kekuatan 
ASMORO ACHMADI: Aksiologi Reog Ponorogo...

gaib dan dapat menguasai alam sekitarnya termasuk alam pikiran dan tingkah laku manusia. ${ }^{21}$ Fauzannafi mengemukakan tentang praktek magis dalam kesenian reog bahwa hingga tahun 1990-an dalam pertunjukan kesenian reog masih dilakukan terutama dalam reog obyogan (reog pedesaan). Nilai ini terungkap pada pemberian unsur daya magis ke dalam kesenian reog khususnya barongan atau pembarong. Unsur magis ini dimaksudkan untuk penambahan daya kekuatan pembarong juga untuk memunculkan daya tarik (aura) bagi group reog.22

\section{Nilai-nilai Spiritual}

Nilai-nilai spiritual, meliputi: a) Nilai budaya. Istilah budaya yang berasal dari kebudayaan meliputi sejumlah total dan organisasi dari warisan sosial yang diterima sebagai suatu yang bermakna yang dipengaruhi oleh watak dan sejarah hidup suatu bangsa. ${ }^{23}$

Budisantosa mengemukakan bahwa sesuatu unsur penting dalam inti kebudayaan adalah nilai-nilai. Nilai budaya adalah asumsi tentang keadaan yang diinginkan atau sebaliknya, anggapan tentang apa yang baik dan buruk, apa yang harus dilakukan dan dihindarkan. Nilai ini terungkap bahwa kesenian reog memuat nilai-nilai kejawaan yang adiluhung, sebagai tontonan dan tuntunan.Kesenian reog sebagai seni-budaya tradisional khas Ponorogo, sehingga kesenian reog menjadi representasi sekaligus sumber nilai bagi masyarakat Ponorogo. ${ }^{24}$ b) Nilai keindahan. Istilah 'indah' secara umum merupakan keadaan enak dipandang, cantik, bagus benar, elok.Keindahan berarti sifat-sifat yang indah, keelokan, kebaikan.Pengertian keindahan dianggap sebagai salah satu jenis nilai, yaitu nilai yang berhubungan dengan segala sesuatu yang tercakup dalam pengertian keindahan yang disebut nilai estetis. ${ }^{25}$ Nilai keindahan ini terungkap pada: (1) gerak tari (warok, jathil, pujangganong, dan barongan), (2) tata busana (warna hitam, merah, kuning, dan putih), (3) tata rias (utamanya tata rias penari jathil dan ganongan), d. aransemen gamelan reog (gendhing kebogiro, gendhing 
ASMORO ACHMADI: Aksiologi Reog Ponorogo...

panaragan, gendhing sampak, gendhing patrajayan, gendhing objog). c) Nilai moral. Istilah 'moral' menurut $\operatorname{Vos}^{26}$ mengemukakan bahwa moral berarti adat-istiadat, dan moral bersangkutan dengan lapisanlapisan yang lebih dalam dari pribadi manusia, dalam arti bersangkutan dengan kepentingan-kepentingan yang lebih dalam dibanding dengan hikum. Beberapa nilai moral yang terungkap, yaitu: jiwa kebersamaan, pengikat kerukunan dan dapat ngrukunake, mewujudkan kegotong-royongan, ajaran reog: ojo dumeh, ojo gumun, ojo pangling, menghindari mo-limo (minuman keras, main wanita, senang makan, main judi, dan mencuri). d) Nilai seni. Istilah seni merupakan proses menciptakan sesuatu yang indah, berguna atau mengherankan oleh budi dengan bantuan dari kemampuan raga manusia. ${ }^{27}$ Artinya, seni sebagai sebuah keahlian membuat karya yang bernilai (dilihat dari segi kehalusannya, keindahannya); karyakarya yang diciptakan dengan keahlian luar biasa seperti tari, lukisan, ukiran. Seni memiliki banyak jenis, seperti: seni-bangunan, seni-budaya, seni-derita, seni drama, seni-lukis, seni-murni, senipahat, seni-panggung, seni-sastra, seni-suara, seni-instrumental, seni-vokal, seni-sungging, dan seni-tari. Nilai seni ini terungkap bahwa kesenian reog sebagai hasil budaya masyarakat Ponorogo.Kesenian reog sebagai seni panggung atau pentas yang dikembangkan melalui festival tahunan dan arak-arakan. e) Nilai simbolik. Kata 'simbol' menurut Endraswara ${ }^{28}$ mengemukakan bahwa kata simbol berasal dari kata Yunani symbolos yang artinya tanda atau ciri yang memberitahukan sesuatu kepada seseorang.Manusia dalam hidupnya selalu berkaitan dengan simbolsimbol yang berhubungan dengan kehidupan sehari-hari.Nilai simbolik ini terungkap bahwa dalam kesenian reog melambangkan Klana Sewandana melamar Dewi Sanggalangit.Dhadhak merak melambangkan sindiran Ki Ageng Kutu terhadap Raja Brawijaya V. Tokoh warok melambangkan: bersemangat, keteladanan, pemberani, kokoh-kuat, berwibawa, siap berkorban, dan jiwa ksatria. Tokoh jathil melambangkan prajurit siap ke medan laga. Tokoh 
ASMORO ACHMADI: Aksiologi Reog Ponorogo...

baronganmelambangkan Raja Singobarong dari kerajaan Lodaya. f) Nilai superioritas. Istilah superioritas berarti keunggulan, kelebihan atau daya linuwih. Tradisi kebudayaan mengungkapkan bahwa kekuatan daya linuwih biasanya berasal dari alam gaib, ilmu kanuragan, atau benda-benda tertentu yang dijadikan benda pusaka (keris, tombak, cincin atau akik, dan benda-benda mistis lainnya. Ilmu kanuragan atau daya linuwih ini datang dan perginya tidak dapat dikuasai sepenuhnya dengan akibat bahwa apabila diperlukan sering ilmu tersebut tidak berfungsi, karena tidak dapat diandalkan maka dalam dunia kebatinan ilmu kanuragan ini dianggap semacam permainan anak-anak.Nilai superioritas ini terungkap bahwa kesenian reog harus memiliki warok yang sakti, dan kepemilikan ilmu kanuragan pada warok (daya linuwih).Para pemain kesenian reog memiliki ilmu kanuragan atau daya linuwih bermanfaat memberikan pesona atau kekuatan tambahan agar reog dan para pemainnya mendapatkan kekuatan ekstra.

\section{Nilai-nilai Kehidupan}

Nilai-nilai kehidupan, meliputi: a) nilai kepahlawanan. Istilah 'pahlawan' berarti orang yang menonjol karena keberanian dan pengorbanannya dalam membela kebenaran atau sesama.Contoh, pahlawan besar seperti Mahapatih Gajah Mada. Kebesaran Gajah Mada bukan terletak pada keturunan raja, tetapi Gajah Mada memiliki nama besar karena cita-cita hidupnya yang mulia, bekerja keras atas terwujudnya Sumpah Palapa yang pernah diucapkan di hadapan raja dan rakyat Majapahit (Nasrudin, 2008: 43). Nilai kepahlawanan ini terungkap bahwa kesenian reog memiliki tokoh pahlawan, seperti tokoh warok.Istilah warok oleh masyarakat Ponorogo diangap sebagai tokoh masyarakat yang memiliki beberapa kelebihan.Kelebihannya seperti memiliki banyak ilmu, memiliki kesaktian/ilmu kanuragan, rela berkorban, pengayom, bekerja tanpa pamrih, dan wira'i.b) Nilai keadilan. Istilah 'adil' berarti tidak berat sebelah atau tidak memihak.Penerapan adil 
ASMORO ACHMADI: Aksiologi Reog Ponorogo...

dalamlingkup kewarganegaraan atau kehidupan bermasyarakat bahwa setiap warga memiliki hak dan kewajiban dalam menciptakan keadilan sosial.Untuk itu dibutuhkan pengembangan perbuatan luhur sebagai cerminan perilaku dan suasana kekeluargaan dan gotong royong, maka dibutuhkan keseimbangan hak dan kewajiban.Nilai keadlan ini terungkap dalam hakikat yang menjadi tujuan akhir kesenian reog.Kesenian reog (terutama warok-nya) mempunyai misi kehidupan.Istilah 'adil' artinya tidak memihak atau berat sebelah.Penerapan keadilan dalam bermasyarakat dan berbangsa adalah pemenuhan hak dan kewajiban.Pemenuhan hak dan kewajiban manusia menurut hakikat kodrat manusia adalah sebagai makhluk individu, sebagai makhluk sosial, dan sebagai makhluk Tuhan.Pemenuhan hak dan kewajiban tersebut ending-nya diharapkan memiliki keseimbangan dan keselarasan hidup baik secara lahiriah maupun batiniah. c) Nilai kesejahteraan. Istilah 'kesejahteraan' berarti hal atau keadaan sejahtera; keamanan; keselamatan; ketenteraman; keselamatan hidup; kemakmuran.Kesejahteraan sangat terkait dengan aspek ekonomi. Kesenian reog mulai tahun 1990-an telah berubah menjadi industri kesenian. Pergeseran nilai yang melandan dunia kesenian ke arah aspek ekonomi menurut Caturwati ${ }^{29}$ telah mengalami perubahan orientasi khususnya melanda seni-budaya.Hal karena banyak orang yang terlibat dalam kesenian reog harus memenuhi keperluan hidup, sehingga muncul istilah 'tanggapan'. Artinya, saat ini kesenian apa saja telah merubah diri dengan menekankan aspek ekonomi. Nilai kesejahteraan ini terungkap bahwa kesenian reog memuat aspek kesejahteraan dengan istilah: uang jamu, bon-bonan, dan tanggapan. Nilai kesejahteraan ini maknanya kehidupan yang tenteram, makmur, dan aman, tetapi nilai tersebut lebih dominan pada aspek ekonomi.Orientasi aspek ekonomi dalam kesenian reog dahulu dan sekarang berbeda.Sekarang, lebih mengarah pada nilai jual sehingga memunculkan industri kesenian, semuanya itu demi menambah kesejahteraan 'konco reog'. 


\section{Nilai-nilai Kesenangan}

Nilai-nilai kesenangan, meliputi: a) Nilai hiburan. Istilah 'hiburan' berarti sesuatu perbuatan yang dapat menyenangkan hati sehingga melupakan kesedihan.Menghibur adalah membuat keadaan senang dan menyejukkan hati yang sedang gundahgulana.Sebuah seni-pertunjukan saat ini lebih besar nilai hiburannya dibandingkan dengan nilai-nilai lainnya.Nilai hiburan kesenian reog pentas dengan reog obyogan berbeda.Nilai hiburan pada reog pentas terletak pada keadaan glamor, sedangkan nilai hiburan pada reog obyogan terletak pada sensualitas dan mabuk-mabukan pemainnya. Nilai hiburan ini terungkap bahwa kesenian reog memiliki daya tarik tersendiri dibanding dengan kesenian lain, seperti: sorak-sorai, keasyikan,kelucuan, mengagumkan, dan mendebarkan. b) Nilai kepuasan. Istilah 'kepuasan' berrati kondisi lega, gembira, kenyang, dst, karena telah memenuhi hasrat hatinya. Nilai ini terungkap pada para pemain setelah selesai pertunjukan terasa puas apa yang diperankan. Penonton juga merasakan puas manakala setelah menyaksikan atraksi pentas kesenian reog.Penanggap (reog obyogan) juga merasakan puas dan senang setelah menanggap reog, karena dapat membuat senang orang banyak. c) Nilai kompetitif. Istilah 'kompetitif' berarti berhubungan dengan persaingan atau kompetisi.Nilai ini terungkap bahwa kesenian reog memuat kompetitif positif dan negatif.Kompetitif positif manakala kesenian reog (reog pentas) dapat dipertandingkan melalui festival tahunan tingkat nasional dan festival tahunan reog mini. Kompetitif negatif (kompetitif tidak sehat) manakala kesenian reog bersaing dengan menjatuhkan group lain. d) Nilai material. Istilah 'material' berarti benda, bahan, segala sesuatu yang tampak, sesuatu yang menjadi bahan.Aspek material kaitannya dengan kesenian reog adalah berhubungan dengan rasa senang.Kesenian reog merupakan sumber untuk mendapatkan kesenangan.Artinya, kesenian reog dapat 
ASMORO ACHMADI: Aksiologi Reog Ponorogo...

dikatakan sebagai hal yang menyenangkan dan membuat rasa senang banyak orang.Nilai material ini terungkap bahwa apabila terdapat interaksi antara subjek dan objek.Kesenian reog dapat memunculkan kesenangan apabila dimainkan, sebaliknya apabila tidak dimainkan tidak memunculkan kesenangan. Beberapa pihak yang disenangkan kesenian reog adalah: penonton, pengrajin, pelatih atau pengajar, pejual souvenir, penjual makanan dan minuman.

\section{Nilai Pertunjukan}

Nilai pertunjukan.Istilah 'pertunjukan' berarti sesuatu yang dipertunjukkan atau tontonan.Kesenian reog memang sebuah kesenian yang dipertunjukkan yang manfaatnya untuk ditonton atau dinikmati para penggemar atau penikmat.Caturwati mengemukakan bahwa sebuah karya tari merupakan suatu kesatuan, keselarasan, serta ketepatan idiom-idiom tersebut.Kesenian reog di dalamnya memuat idiom-idiom, seperti dalam reog obyogan idiom-idiomnya adalah gerak, cerita, tema, tata busana, iringan musik, dsb.Nilai pertunjukan ini terungkap bahwa kesenian reog memiliki dua jenis pertunjukan, yaitu pertunjukan di panggung (reog pentas) pentas dan pertunjukan bukan di panggung (reog objogan). ${ }^{30}$

\section{E. Relevansi Nilai-nilai Kesenian Reog Ponorogo dengan Pembangunan Karakter Bangsa}

Istilah 'karakter' sebagai sistem daya juang meliputi daya dorong, daya gerak, dan daya hidup, dan berisi tata nilai kebajikan moral yang terpatri dalam diri manusia. Hidayatullah mengemukakan bahwa karakter memungkinkan perusahaan atau individu untuk mencapai pertumbuhan yang berkesinambungan karena karakter memberikan konsistensi, integritas, dan energi. Jenis karakter manusia ada yang tangguh dan ada yang lemah. Manusia yang berkarakter tangguh akan selalu menyempurnakan diri walau mengadapi tekanan. Manusia yang berkarakter lemah cenderung 
ASMORO ACHMADI: Aksiologi Reog Ponorogo...

pasrah (nasib) kondisi diri yang ada. ${ }^{31}$ Kondisi bangsa Indonesia menurut Koentjaraningrat dan Muchtar Lubis mengemukakan bahwa bangsa Indonesia lebih memiliki karakter lemah, karena memiliki sifat-sifat meremehkan mutu, etos kerja buruk, tidak punya malu, suka menerobos, tidak percaya diri, dan tidak disiplin. ${ }^{32}$ Masalahnya sekarang, bagaimana agar manusia-manusia Indonesia memiliki karakter tangguh.

Menanggulangi permasalahan tersebut tidaklah mudah bagi bangsa Indonesia. Di era reformasi muncul berbagai krisis, seperti: krisis ekonomi, merebaknya korupsi, kekerasan, pornografi, dan radikalisme, sehingga berakibat melemahnya pada karakter bangsa. Penanggulangannya adalah penguatan terhadap 'Empat Pilar' (Pancasila, UUD 1945, Bhineka Tunggal Ika, dan NKRI) berbangsabernegara, nilai kebangsaan, dan nilai patriotisme.Apakah seni tradisional reog Ponorogo dapat dipakai sebagai upaya membangun karakter bangsa.Pendalamannya, bahwa nilai kebangsaan dan nilai patriotisme dalam kesenian reog dapat direfleksikan ke arah pembangunan karakter bangsa.Upaya kultivasi seni-budaya dalam perspektif yang lebih luas.Meningkatkan fungsi ekspresif dan fungsi instrumental terhadap nilai-nilai kesenian reog.Hal ini sejalan dengan keberadaan seni tradisional harus dilihat dari fungsi ekspresif dan instrumental.Fungsi ekspresif menunjukkan bahwa kesenian reog dengan peran utamanya terkait dengan kedudukan sosialnya.Fungsi instrumental menunjukkan bahwa kesenian reog dapat dijadikan media penyampaian pesan hal-hal yang terkait dengan pembangunan nasional.

Sejajalan dengan kondisi bangsa, nilai-nilai kesenian reog dapat memberikan kontribusi terhadap penegakan empat pilar berbangsa dan bernegara melalui nilai patriotisme yang terungkap dalam diri warok. Penguatan 'Empat Pilar' terungkap dalam kesesuaian antara nilai-nilai kesenian reog Ponorogo dengan nilai-nilai Pancasila, yaitu: a) Nilai kepercayaan berkesesuaian dengan nilai ketuhanan, b) Nilai 
ASMORO ACHMADI: Aksiologi Reog Ponorogo...

kepribadian berkesesuaian dengan nilai kemanusiaan, c) Nilai hiburan dan pertunjukan berkesesuaian dengan nilai persatuan, d) Nilai sosial (rukun) berkesesuaian dengan nilai kerakyatan, e) Nilai kesejarahan dan kelestarian berkesesuaian dengan nilai keadilan.

Tokoh warok yang menjadi agul-agule wong Ponorogo (kebanggaan masyarakat Ponorogo) dalam kesenian reog berperan sebagai tokoh sentral. Tokoh warok dianggap sebagai manusia berkualitas menurut pemikiran masyarakat Ponorogo. Di setiap barisan kesenian reog apabila sedang berjalan, maka tokoh warok menempati posisi depan seperti komandan barisan perang dan terlihat menyeramkan. Sehingga, tokoh warok harus memiliki kesaktian, ketangguhan, dan berwibawa.Tokoh warok merupakan tokoh utama dan sentral dalam kesenian reog dan masyarakat Ponorogo. Kaitannya dengan nilai-nilai kesenian reog apabila direfleksikan sesuai sifat-sifat tokoh-tokoh reog (warok, klana, jathil, dan barongan) muncul lima kebajikan esensial, yaitu:

1. Refleksi nilai kepahlawanan upaya membangun karakter bangsa (sifat pengorbanan). Sifat yang utama seorang pahlawan adalah bersedia mengorbankan baik jiwa dan raganya tanpa mengharap balas jasa. Seorang pahlawan lebih mendahulukan kewajiban dari pada menuntut apa yang menjadi haknya.

2. Refleksi nilai kewiraan membangun karakter bangsa (sifat pemberani dan pantang menyerah). Sifat yang utama selain pengorbanan adalah pemberani dan pantang menyerah. Berani mengambil resiko apa yang dilakukan dan pantang menyerah dalam meraih cita-cita perjuangannya.

3. Refleksi nilai superioritas upaya membangun karakter bangsa (sifat daya linuwih). Sifat yang utama selain bersemangat, rela berkorban, pemberani, dan pantang menyerah adalah memiliki 
ASMORO ACHMADI: Aksiologi Reog Ponorogo...

daya-linuwih.Daya-linuwih diartikan sebagai sifat yang dimiliki seorang yang mengungguli sifat-sifat manusia kebanyakan.

4. Refleksi nilai kepribadian upaya membangun karakter bangsa (sifat keperkasaan atau tangguh). Sifat yang utama selain berkorban, pemberani, pantang menyerah dan memiliki dayalinuwih adalah ketangguhan.Sifat tangguh memiliki pemahaman tangguh fisik dan non-fisik (tangguh mental).

5. Refleksi nilai moral upaya membangun karakter bangsa (sifat keteladanan atau perekat). Sifat yang utama selain pemberani, pantang menyerah, memiliki daya-linuwih, dan tangguh juga sebagai pahlawan juga dapat memberikan keteladanan terhadap masyarakat.

Upaya membangun karakter bangsa yang sedang melemah saat ini dapat dicari dalam nilai-nilai yang terungkap dalam kesenian reog. Nilai-nilai tersebut apabila ditranformasikan dalam diri setiap warga negara akan muncul spirit-spirit yang akan menetes kepada siapa saja yang memiliki kemampuan menangkap nilai-nilai kesenian reog. Spirit-spirit yang muncul pertama kali adalah kesadaran dan semangat hidup (elan vital) untuk berbuat sesuai karakter para pahlawan. Spirit-spirit tersebut akan merefleksi (meresap) dalam diri setiap orang sehingga mengakibatkan kesadaran dan semangat hidup tersebut menyala-nyala. Semangat yang menyala-nyala terungkap dalam ujud lahir maupun batin para pemainnya.

\section{F. Penutup}

Kesenian reog Ponorogo memiliki sejarah panjang, melegenda, dan menjadi kebanggaan masyarakat Ponorogo.Sejarah panjang kesenian reog dan perkembangannya dimulai dari kerajaan Wengker hingga sekarang.Kesenian reog dikatakan melegenda, karena kesenian reog sangat erat kaitannya dengan tokoh legendaris Bahtara Katong sebagai Bapak-e Wong Ponorogo. Sejarah panjang kesenian reog berhasil melewati pasang-surut perjalanan waktu 
ASMORO ACHMADI: Aksiologi Reog Ponorogo...

mulai kerajaan Wengker, kerajaan Bantarangin, zaman Bathara Katong, zaman penjajahan Belanda dan Jepang, zaman setelah kemerdekaan atau Orde Lama, zaman orde baru, dan zaman reformasi. Karakter seni-budaya kesenian reog memiliki kesamaan karakter masyarakat Ponorogo, sehingga dengan kesamaan karakter tersebut masyarakat Ponorogo mampu memelihara, mempertahankan, dan melestarikannya.

Nilai-nilai kesenian reog Ponorogo apabila dilihat dari konsep nilai Max Scheler, meliputi: a) Nilai-nilai kerohanian yaitu memuat unsur-unsur batiniah seperti penjiwaan pada setiap pemain reog (meliputi: nilai dakwah, nilai kelestarian, nilai kepercayaan, dan nilai magis); b) Nilai spiritual yaitu memuat hal-hal yang melahirkan gairah dan getaran jiwa (meliputi: nilai budaya, nilai keindahan, nilai moral, nilai seni, nilai simbolik, dan nilai superioritas); c) Nilai kehidupan yaitu memuat unsur-unsur lahiriah yang berkaitan dengan keperluan hidup keseharian (meliputi: nilai kepahlawanan, nilai keadilan, dan nilai kesejahteraan); d) Nilai kesenangan yaitu memuat unsur-unsur pada pembiasan hidup positif (meliputi: nilai hiburan, nilai kepuasan, nilai kompetitif, nilai material, dan nilai pertunjukan).

Kondisi bangsa saat yang sedang dilanda berbagai masalah, seperti merebaknya korupsi, terorisme, krisis moralitas, kekerasan, dan berbagai ideologi yang kurang sesuai dengan Pancasila. Kondisi demikian akan melemahkan karakter bangsa, apabila dibiarkan bangsa Indonesia akan terjerumus ke dalam bangsa tuna-budaya dan tuna moral. Penanggulangannya, upaya menguatan nilai-nilai kebajikan esensial seperti yang terungkap dalam siprit-spirit yang terungkap dalam kesenian reog.Nilai kesenian reog Ponorogo khususnya nilai warok dapat ditransformasikan dalam upaya membangun karakter bangsa. Nilai warok tersebut adalah ketangguhan, pemberani, pantang menyerah, dan patriotik.[] 


\section{Catatan Akhir}

${ }^{1}$ The Liang Gie, Suatu Konsepsi ke Arah Penertiban Bidang Filsafat, terj. Ali Mudhofir, Yogyakarta: Tiara Wacana Press, 1977, h. 40 .

${ }^{2}$ Soedarsono, Pengantar Sejarah Kesenian I-II, Yogyakarta: ISI Yogyakarta, 1994, h. 48.

${ }^{3}$ Koentjaraningrat, Kebudayaan Jawa, Jakarta: Balai Pustaka, 1984, h. 225-226.

${ }^{4}$ Syahrial Syarbaini, Pendidikan Pancasila: Implementasi Nilainilai Karakter Bangsa, Jakarta: Ghalia Indonesia, 2009, h. 132.

5Risieri Frondizi, What is Value?: An Introduction to Axiology, LaSalle, Ill. : Open Court Pub Co, 1963, h. 82-83.

${ }^{6}$ The Liang Gie, Suatu Konsepsi., h. 145-146.

${ }^{7}$ Louis O. Kattsoff, Pengantar Filsafat, terj. Soejono Soemargono, Yogyakarta: Tiara Wacana, 1986, h. 328-329.

${ }^{8}$ Harold H. Titus, Marylin S. Smith, Richard T. Nolan, PersoalanPersoalan Filsafat, terj. H. M. Rasyidi, Jakarta: Bulan Bintang, Jakarta, h. 123-124.

${ }^{9}$ Risieri Frondizi, What is Value?, h. 94-102.

${ }^{10}$ Kaelan, Filsafat Pancasila: Pandangan Hidup Bangsa, Yogyakarta: Paradigma, 2005, h. 80.

11Ibid., h. 254.

${ }^{12}$ Purwowijoyo, Babad Ponorogo I - VIII, Ponorogo: t.p., 1984, h. 32.

13Ibid., I, h. 5.

${ }^{14}$ Pramono Muh. Fajar, Raden Bathara Katong Bapak-e Wong Ponorogo, Ponorogo: Lembaga Penelitian Pemberdayaan Birokrasi dan Masyarakat Ponorogo, 2006, h. 7.

15Purwowijoyo, Babad Ponorogo., I, h. 13-14.

16Ibid., I, h. 33-34.

17Ibid., h. 34.

18Widji Saksono, Mengislamkan Tanah Jawa, Bandung: Mizan, 1995, h. 221.

${ }^{19}$ Muh. Zamzam Fauzannafi, Reog Ponorogo Memori diantara Dominasi dan Keragaman,Yogyakarta: Kepel, 2005, h. 79.

20Suwardi Endraswara, Budi Pekerti Jawa, Yogyakarta:

Gelombang Pasang Press, 2006, h. 162.

${ }^{21}$ Koentjaraningrat, Kebudayaan Jawa, h. 54. 
22Muh. Zamzam Fauzannafi, Reog Ponorogo., h.171.

23Deddy Mulyana dan Jalaluddin Rakhmat.Komunikasi Antarbudaya:Panduan Berkomunikasi dengan Orang-Orang Berbeda Budaya, Bandung: Remaja Rosdakarya, 2006, h. 25.

${ }^{24}$ Budhisantoso, "Kesenian dan Kebudayaan", Jurnal Seni, Juli 1994, STSI Press, Surakarta, h. 50.

${ }^{25}$ Kartini, Horizon Estetika, Yogyakarta: Badan Penerbitan Fakultas Filsafat UGM, 2008, h. 35

26De Vos, Pengantar Etika, terj. Soejono Soemargono, Yogyakarta:

Tiara Wacana, 1987, h. 66.

27The Liang Gie, Suatu Konsepsi., h. 36.

${ }^{28}$ Suwardi Endraswara, Budi Pekerti Jawa, h.171.

${ }^{29}$ Endang Caturwati, Tari di Latar Sunda, Bandung: STSI Bandung, 2007, h. 169.

30Ibid., h. 169.

${ }^{31}$ Furqon Hidayatullah, Pendidikan Karakter: Membangun Peradaban Bangsa, Surakarta: Yuma Pustaka Hidayatullah, 2010, h. 15.

${ }^{32}$ Lihat: Saptono, Dimensi-dimensi Pendidikan Karakter, Surabaya: Erlangga, 2011, h. 19. 


\section{DAFTAR PUSTAKA}

Budhisantoso, "Kesenian dan Kebudayaan”, Jurnal Seni, Juli 1994, STSI Press, Surakarta.

Caturwati, Endang, Tari di Latar Sunda, Bandung: STSI Bandung, 2007.

De Vos, Pengantar Etika, terj. Soejono Soemargono, Yogyakarta: Tiara Wacana, 1987.

Endraswara, Suwardi,Budi Pekerti Jawa, Yogyakarta: Gelombang Pasang Press, 2006.

Fajar, Pramono Muh., Raden Bathara Katong Bapak-e Wong Ponorogo, Ponorogo: Lembaga Penelitian Pemberdayaan Birokrasi dan Masyarakat Ponorogo, 2006.

Fauzannafi, Muh. Zamzam, Reog Ponorogo Memori diantara Dominasi dan Keragaman,Yogyakarta: Kepel, 2005.

Frondizi, Risieri, What is Value?: An Introduction to Axiology, LaSalle, Ill. : Open Court Pub Co, 1963.

Gie, The Liang, Suatu Konsepsi ke Arah Penertiban Bidang Filsafat, alih bahasa: Ali Mudhofir, Yogyakarta: Tiara Wacana Press, 1977.

Hidayatullah, Furqon, Pendidikan Karakter: Membangun Peradaban Bangsa, Surakarta: Yuma Pustaka Hidayatullah, 2010.

Kaelan, Filsafat Pancasila: Pandangan Hidup Bangsa, Yogyakarta: Paradigma, 2005.

Kartini, Horizon Estetika, Yogyakarta: Badan Penerbitan Fakultas Filsafat UGM, 2008, h. 35

Kattsoff, Louis O., Pengantar Filsafat, terj. Soejono Soemargono, Yogyakarta: Tiara Wacana, 1986.

Koentjaraningrat, Kebudayaan Jawa, Jakarta: Balai Pustaka, 1984. 
Mulyana, Deddy, dan Jalaluddin Rakhmat. Komunikasi Antarbudaya:Panduan Berkomunikasi dengan Orang-Orang Berbeda Budaya, Bandung: Remaja Rosdakarya, 2006.

Purwowijoyo, Babad Ponorogo I - VIII, Ponorogo: t.p., 1984.

Saksono, Widji ,Mengislamkan Tanah Jawa, Bandung: Mizan, 1995.

Saptono, Dimensi-dimensi Pendidikan Karakter, Surabaya: Erlangga, 2011.

Soedarsono, Pengantar Sejarah Kesenian I-II, Yogyakarta: ISI Yogyakarta, 1994.

Syarbaini, Syahrial, Pendidikan Pancasila: Implementasi Nilai-nilai Karakter Bangsa, Jakarta: Ghalia Indonesia, 2009.

Titus, Harold H., et.al., Persoalan-Persoalan Filsafat, terj. H. M. Rasyidi, Jakarta: Bulan Bintang, Jakarta, 1984. 